\section{Manuskripter på Nettet - nogle perspektiver og problemstillinger}

Af forskningsbibliotekar, mag.art. Bruno Svindborg

$\mathrm{D}$ igitalisering er en relativ ny teknik, der har vundet indpas og fundet anvendelse i mange forskellige og nye sammenhænge gennem de seneste par årtier. Vækkeuret angiver tiden med en uhyre præcision uden det obligate tik-tak. Til gengæld ophæves tid og sted på det nærmeste på Internettet med risiko for masser af 'støj'.

Ikke mindst indenfor biblioteksverdenen er digitalisering i løbet af 90'erne blevet et in-ord. Og med god grund. Utallige er de artikler og bøger, der er skrevet og vil blive skrevet om denne teknik, der med hensyn til omformningen af vort liv og samfund forudses at blive så revolutionerende, at den sågar er blevet sammenlignet med Gutenbergs opfindelse af bogtrykteknikken i midten af 1400-tallet. Og utallige er de digitaliseringsprojekter, som nationalbiblioteker, forskningsbiblioteker og specialbiblioteker har igangsat især siden midten af 90 'erne, ikke mindst som følge af de nye kommunikationsmuligheder, som den eksplosive udvikling på Internettet med anvendelsen af World Wide Web har muliggjort.

Selvom det ikke er vanskeligt at få øje på det konkurrencemoment, der spiller ind i opkomsten af alle disse projekter ("So ein Ding müssen wir auch haben"), så er det på den anden side heller ikke svært at se de muligheder, de indebærer for bibliotekerne og deres brugere.

Det er indlysende, at digitaliseringsteknikken, der kan ændre vores arbejde, uddannelse og fritid drastisk i de kommende år, som vil give nye 'samværsmuligheder' og muliggøre nye kommunikationsformer, fordrer analyser af disse muligheders implikationer, men også af teknikkens begrænsninger.

Af det problemkompleks, som de mere visionære betragtninger over digitaliseringens muligheder lægger op til: eksistentielle, æstetiske, etiske, økonomiske, juridiske, politiske og tekniske, er udgangspunktet for de følgende betragtninger imidlertid langt mere beskedent, i og med at der i forhold til digitaliseringens mange anvendelsesmuligheder fokuseres på noget så 'sektorspecifikt' som biblioteksverdenen, og indenfor denne endnu mere snævert på digitalisering af manuskripter.

'Manuskripter' forstås som alle typer af unika, altså som det eneste eksisterende af sin art, hvad enten der er tale om eksempelvis et illumineret middelaldermanuskript på pergament, en håndskrevet dagbog eller et brev, skrevet på maskine. At der er tale om unikt materiale, er naturligvis ikke ensbetydende med, at digitalisering af manuskripter ikke har perspektiver og problemstillinger fælles med digitalisering af andre typer af biblioteksdokumenter: bøger, tidsskrifter, fotografier m.v. Ikke desto mindre er der faktisk problemstillinger, der er specifikke, når materialetypen er manuskripter, ligesom der 
omvendt er opgaver, man kan lade ude af betragtning. Eksempelvis kan digitaliseringen af et manuskript aldrig erstatte dokumentet som sådant, forstået på den måde, at dokumentet efter digitaliseringen af pladsmæssige eller andre grunde kunne destrueres. $\mathrm{Og}$ på den anden side er problemstillingerne vedr. anvendelsen af OCR-teknikken, der konverterer et fysisk dokument til maskinlæsbar form, ikke umiddelbart relevante, når talen er om manuskripter, af den simple grund at man ikke har udviklet en teknologi, der gør det muligt at 'læse' manuskriptet med et blot nogenlunde tilfredsstillende resultat, og heller ikke regner med at kunne gøre det $i$ en overskuelig fremtid. Til gengæld er der m.h.t. perspektiverne nogle ekstra gevinster at hente, i og med at der netop er tale om unikt materiale, dvs. originale dokumenter, der af sikringsmæssige grunde ikke udlånes, men udelukkende kan benyttes på de enkelte bibliotekers læsesale.

\section{Digitaliseringskæden}

$\mathrm{P}$ å mit skrivebord har jeg udprintninger liggende fra 4 notesbøger af Walt Whitman, som efter at være forsvundet i 50 år blev genfundet og afleveret til Library of Congress for et par år siden. På grund af notesbøgernes enestående værdi og deres skrøbelighed - de er skrevet med blyant - vurderede man på biblioteket, at de ikke skulle være tilgængelige for almindelig benyttelse. Til gengæld og som 'erstatning' for originalerne valgte man efter en omhyggelig restaurering at digitalisere dem og gøre dem tilgængelige over Internettet ${ }^{1}$. Disse udprintninger anskueliggør digitaliseringens umiddelbare fordele, og de er samtidig sidste led i en digitaliseringskæde, der grundlæggende indeholder følgende led: Materialeforberedelse $\rightarrow$ Digitalisering og indeksering $\rightarrow$ Billedefterbehandling $\rightarrow$ Netvark $\rightarrow$ Skarmbillede/Udprintning. De enkelte led i denne kæde, der indbefatter såvel objektive som subjektive faktorer, udgør en sammenhæng, hvor det afgørende er, at resultatet, i det foreliggende tilfælde udprintningerne, er et produkt af kæden som helhed. En afgørende konklusion er følgelig, at det endelige produkt (skærmbillede/udprintning) ikke kan blive bedre, end kædens svageste led tillader det.

Uanset denne konklusion er det helt afgørende led naturligvis selve digitaliseringen af dokumentet og dennes kvalitet. Med digitalisering har man at gøre med det, som Nicholas Negroponte populært har kaldt for "informationernes dna", at udskifte atomer med bits. Analoge data udskiftes med digitale. Når et dokument repræsenteres analogt, repræsenteres det i form af kontinuerlige variationer langs et kontinuerligt spekter. Når det repræsenteres digitalt, overføres det til talform, dvs. det repræsenteres i form af diskrete variationer over et diskontinuerligt spekter af værdier. At information (et dokument) digitaliseres, betyder altså, at den (det) overføres til talform, som er det eneste computeren 'forstår'.

Dette grundlæggende, uanset om man har at gøre med eksempelvis tekst, lyd eller billede. Ved digitaliseringen af manuskripter drejer det sig om billeddigitalisering, dvs. ved hjælp af et 

digitalt kamera at frembringe et elektronisk fotografi, der ideelt set scannes fra det originale dokument og repræsenterer det $\mathrm{i}$ alle dets aspekter.

Den afgørende forskel mellem analog og digital representation er ikke kvaliteten (jvf. den hidsige diskussion blandt hi fi-entusiaster, da musikcd'en erstattede lp-pladen). Heller ikke m.h.t. billeder er det kvalitetsforskellen som sådan, der gør digitale billeder uovertrufne. Det der fremfor alt adskiller dem fra analoge billeder, er at de kan transmitteres over netværk, og at de er lette at manipulere med.

Billeddigitaliseringen foregår ved at inddele billedet i punkter ("dots") og give hver punkt en værdi. I billeddigitaliseringen kaldes hver punkt en pixel, der er en forkortelse for "picture element". Og den værdi hver enkelt punkt eller pixel har, kaldes for pixeldybden. Et digitalt billede kan altså varieres på to måder:

- Man kan øge eller mindske antallet af punkter, eller pixels i billedet, dvs. bestemme hvor mange punkter en tomme af dokumentet skal repræsenteres med digitalt ("dots per inch" $=d p i$.

- Man kan øge eller mindske pixeldybden, der er den værdiskala, den enkelte pixel kan have, dvs. bestemme, hvor vidt representationen skal være sort/hvid eller farve, og hvis farve, hvor mange farvenuancer, der skal være til rådighed i den enkelte pixel.

Såvel antallet af pixler som pixeldybden udmåles $i$ bits, eller med andre ord: jo højere det digitale billedes opløsning er, og dermed dets kvalitet, jo større fil er nødvendig for at rumme billedet, og som konsekvens heraf: jo længere tid vil det tage at transmittere det.

Dette entydige forhold mellem billedkvalitet og filstørrelse (og transmissionshastighed) stiller nogle interessante spørgsmål til digitaliseringsprojekter $i$ almindelighed og til digitalisering af manuskripter i særdeleshed. I den konkrete digitalisering og i overvejelserne inden man starter et digital iseringsprojekt er der al mulig grund til at være 'økonomisk', forstået på den måde at det ideelle ønske om den størst mulige gengivelseskvalitet, der jo i sin kerne én gang for alle er afhængig af det digitaliserede billedes kvalitet, må sættes i relation til andre sammenhængende faktorer, så som objektets fysiske og indholdsmæssige karakteristika, den påregnede anvendelse af billedet, brugernes nuværende - og ikke mindst fremtidige - forventninger og behov.

\section{Bevaring og/eller tilgængelighed}

“D $\begin{aligned} & \text { reservation" og "access" er to af } \\ & \text { nøglebegreberne indenfor den } \\ & \text { omfattende digitaliseringslitte- }\end{aligned}$ ratur. I mange af de igangværende projekter formuleres det som et eksplicit formål med digitaliseringen på én gang at bevare og tilgængeliggøre dokumentet.

Som jeg nævnte indledningsvis, kan det ikke være formålet med digitaliseringen af manuskripter at "bevare" dokumentet i den forstand, at det elektroniske dokument $\mathrm{i}$ bogstavelig betydning erstatter det fysiske originaldokument. Det digitale billede bliver prin- 
cipielt ikke, således som det kan blive tilfældet ved andre materialetyper som bøger og tidsskrifter på grund af papirnedbrydning eller kassation, den egentlige primærkilde. Dette betyder, at begreberne "bevaring" og "tilgængelighed", der naturligvis også er nøglebegreber i forbindelse med digitalisering af manuskripter, har delvis andre implikationer end ved de nævnte materialetyper.

Bevaringsformålet har to aspekter. Det første vedrører sikkerheden ved at at have en digital kopi, såfremt originalen på grund af tilsigtede eller utilsigtede ydre faktorer går tabt (tyveri, hærværk, brand). Det diskuteres i denne sammenhæng for øjeblikket heftigt, hvorvidt digitale kopier kan/skal erstatte den sikkerhedsfotografering, der hidtil i langt overvejende grad er blevet foretaget på sort/hvide mikrofilm. En diskussion, der ikke blot indbefatter den åbenlyse kendsgerning, at digitale billeder i farver er lettere at håndtere og kan repræsentere originalen bedre end mikrofilmen og kan transmitteres, men også den usikkerhed med hensyn til digitale billeders holdbarhed, der uanset accelerationstests stadig gør sig gældende - og som jo er afgørende $i$ en bevaringsdiskussion -, set $i$ lyset af et velprøvet medium som mikrofilmen, der med anvendelsen af den materialekvalitet, der er til rådighed $\mathrm{i}$ dag, og med opbevaring under optimale klimatiske forhold, kan garantere en holdbarhed på 100 år og derover.

Det andet aspekt vedrører det forhold, at det digitale billede skal erstatte det formål, som brugeren ellers kun ville fa indfriet ved brug af originalen, der kan være så skrøbelig, at den ikke kan udsættes for slid, eller så værdifuld, at brugen udgør en uacceptabel sikkerhedsrisiko. Dette stiller naturligvis nogle specifikke krav til billedkvaliteten, der må være så god, at man på de enkelte biblioteker så at sige med god samvittighed kan nægte at stille originalerne til rådighed og henvise til deres digitale repræsentation og altså eliminere eller $\mathrm{i}$ hvert fald kraftigt reducere brugen af $\mathrm{dem}^{2}$.

Det digitale billede, der transmitteres over netværk, er ikke en kopi af den oprindelige optagelse, men en variant af "masteren", der er tilpasset den funktion, at det skal transmitteres under de gældende teknologiske betingelser. Konkret betyder det først og fremmest, at den originale masterfil er komprimeret til en afledt fil med en størrelse, der gør den transmitterbar indenfor en rimelig tid. Men som alle ved, ændrer disse betingelser sig med forrygende hast. Det er derfor afgørende, at "masteren" har en arkivalsk kvalitet, der såvel af bevaringsmæssige som af økonomiske grunde i princippet sikrer, at manuskriptet ikke senere skal gennem endnu en digitalisering, og at den som forudsætning herfor kan tilgodese forskellige funktioner i biblioteket og brugernes behov i nutid og den fremtid, som på nuværende tidspunkt kan forudses. 


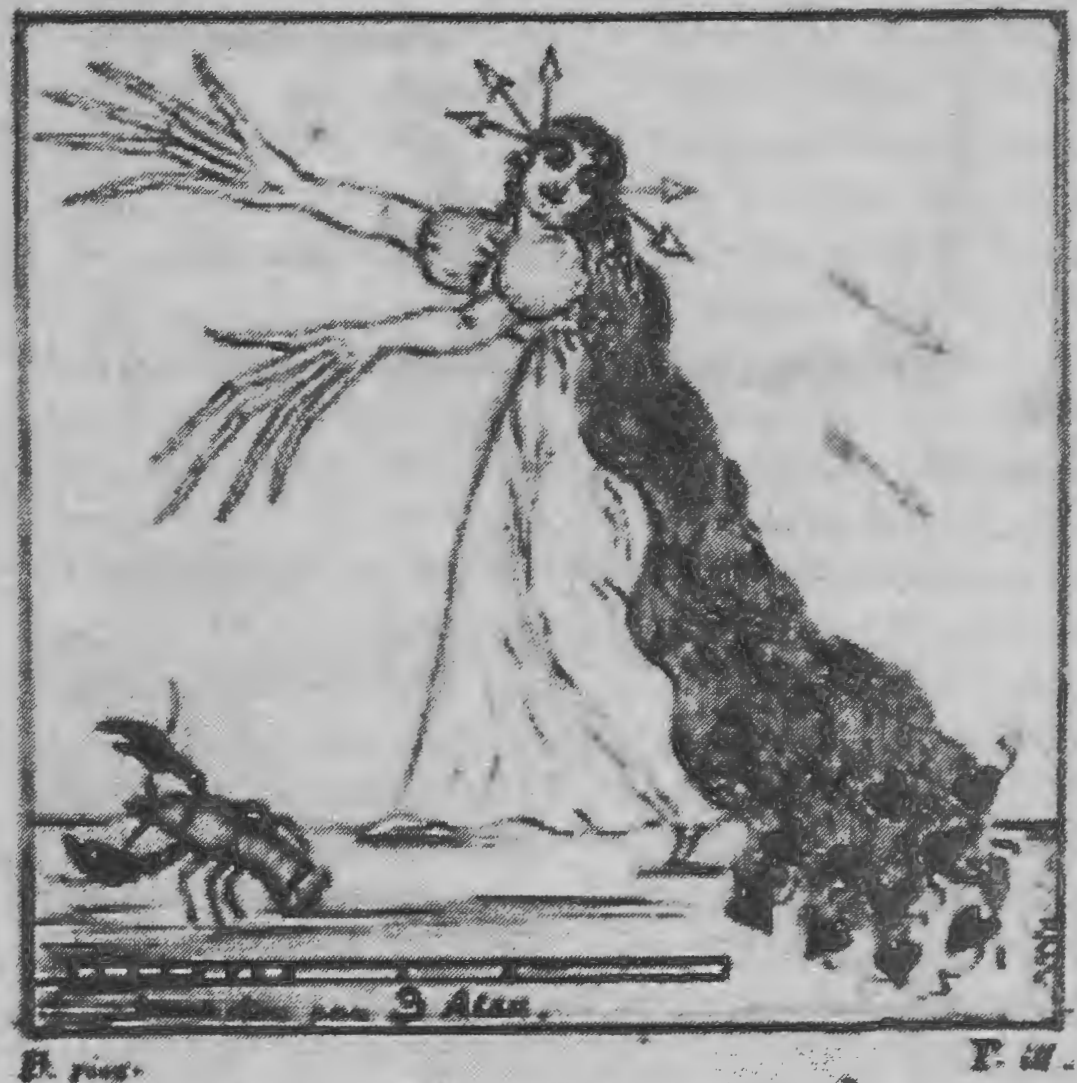

Mer seer of yor Feollerader. Brima,

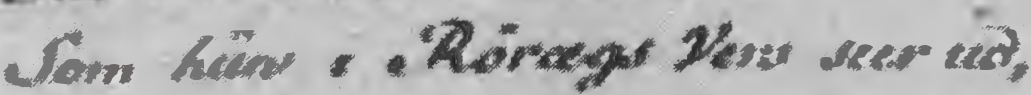

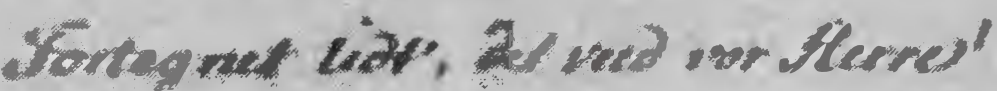

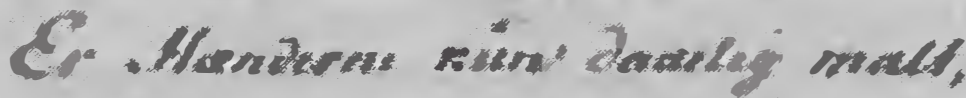

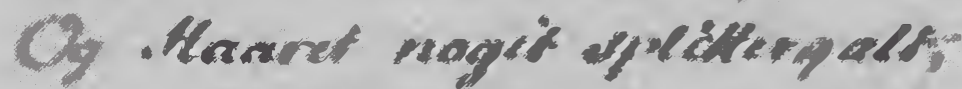

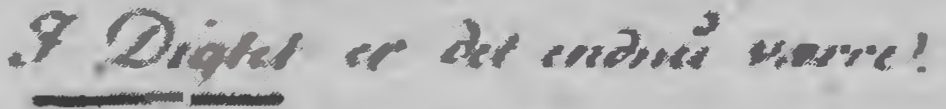

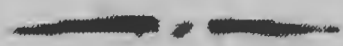

Illustration fra Jens Baggesens "Epigrammatisk Billedbog", der er det forste manuskript, som Håndskriftafdelingen vil legge på Nettet i sin helhed. 
Digitalisering af manuskripter

$\mathrm{M}$ asteren skal altså tilgodese begge aspekter af begrebet "bevaring", der er omtalt ovenfor, altså en arkivalsk funktion og sammenhængende hermed en tilgængelighedsfunktion. Det har i denne sammenhæng været diskuteret, hvor vidt man kunne sætte nogle standarder for den kvalitet, der kunne sikre disse funktioner $^{3}$. Denne diskussion har vist sig at være temmelig ørkesløs, ikke blot fordi de teknologiske muligheder havde ændret sig så at sige fra tankerne havde meldt sig til de stod at læse på tryk, men også på grund af den forskelligartethed, som manuskripter repræsenterer $i$ alle henseender.

Manuskripter er som materialetype yderst inhomogen. Typiske former for dokumenter vil være et illumineret middelaldermanuskript, skrevet på pergament, og breve, dagbøger, udkast og optegnelser, skrevet med pen og blæk, blyant eller på skrivemaskine. $\mathrm{Og}$ også indenfor hver af disse dokumenttyper - og i det enkelte dokument - kan der være store forskelle. De enkelte middelaldermanuskripter har forskellig pergament- og blækfarve, og der kan i det enkelte manuskript være indførsler med forskellige 'hænder', der kun kan identificeres gennem blækfarven. Endelig vil illuminerede manuskripter indeholde illustrationer, ornamenteringer og 'brødskriften' som sådan af stor detaljerigdom og skønhed. Breve og dagbøger m.m. er oftest skrevet $i$ hånden med blæk eller blyant på papir med forskellig farve. Skriften er ofte vanskelig at tyde, hvad enten det skyldes en 'ulæselig' håndskrift, en diminuativ skrift, falmede partier på grund af lys eller skrivemedium (blyant), kaotisk sidelayout (randbemærkninger, overstregninger, senere tilføjelser). Og også maskinskrevne manuskripter vil oftest indeholde andre informationer end brødteksten som sådan: forskellige farver, håndskrevne tilføjelser, indsatte illustrationer. Dette kun for at give indtryk af de udfordringer man stilles overfor i digitaliseringen af manuskripter.

Med alle disse variabler er det klart, at der i digitaliseringen ikke findes nogen mulighed for automatik. Hvert dokument og hver side i et dokument kan kræve nye overvejelser og indstillinger. Det er på denne baggrund ikke overraskende, at der er forskellige opfattelser af, hvilke 'tekniske' krav man skal stille til de forskellige manuskripttyper, underforstået at samtlige typer af informationer skal bevares. Det er i den sammenhæng blevet fremhævet, at spørgsmålet om, hvad der er en væsentlig detalje, ofte er en subjektiv afgørelse. Dette kan være rigtigt nok i den forstand, at f.eks. forskere af middelalderhåndskrifter kan have forskellige interesser i og altså forskellige tilgange til det enkelte manuskript: nogle er primært interesseret i teksten, andre i illustrationerne andre igen $i$ informationer vedr. bind, pergament/papir og vandmærker. Til gengæld bør spørgsmålet om, hvorvidt det digitale billede repræsenterer samtlige væsentlige informationer i en manuskriptside ikke være en subjektiv afgørelse, men skal besvares intersubjektivt i et samarbejde mellem 'teknikere' og 'bibliotekarer'. 
Som nævnt ovenfor er der i tilgængelighedsøjemed en række umiddelbare fordele forbundet med et digitaliseret manuskript i forhold til mikrofilm. Ikke blot i den åbenlyse forstand, at det kan benyttes uafhængig af tid og sted, men også på grund af de muligheder for manipulation med de enkelte billeder, som udviklingen af soft ware har gjort mulig for såvel producent som bruger. Producenten har mulighed for at 'forbedre' billedet, dvs. ved hjælp af forskellige teknikker at gøre bestemte informationer $i$ originalen lettere tilgængelige. Rent bortset fra at en sådan billedefterbehandling er tidrøvende og altså vil fordyre et digitaliseringsprojekt, så er det af 'purister' blevet fremhævet, at en sådan fremgansmåde er uetisk, og at det under alle omstændigheder bør ekspliciteres, hvor originalen er blevet 'forbedret'. Brugeren har mulighed for at forstørre og fokusere på detaljer i billedet, indsætte det $i$ andre dokumenter og printe det ud m.v.

Ikke mindst en udprintning kan være et udmærket udgangspunkt for en vurdering af, hvorvidt det transmitterede digitale billede har en kvalitet, der gør det egnet som substitut for originalen. Man kan ikke forvente, at et manuskript på flere hundrede sider, der er tilgængeliggjort på Nettet, i sin helhed studeres på skærmen. Store dele af det vil formentlig blive printet ud, hvorefter der vendes tilbage til skærmen for studiet af illustrationer, detaljer m.v. Man bør altså kunne forlange, at i hvert fald de informationer, der vedrører det rent tekstlige er umiddelbart tilstede i en udprintning. At en stor del af de (dele af) manuskripter, der i dag er tilgængelige ikke kan honorere dette krav, er ikke uafvendeligt. Man har i en naturlig begejstring og benovelse over den nye teknik i mange tilfælde været mere optaget af at fokusere på illustrative og demonstrative formål, der bærer præg af en udstillingsvirksomhed, der naturligvis er al ære værd, end de egentlige forskningsmæssige anvendelsesmuligheder, der nu hvor benovelsen har lagt sig og erfaringerne indhøstet, er og må være den centrale bestræbelse for igangværende og kommende digitaliseringsprojekter. En relativ simpel foranstaltning $i$ den henseende kunne være, at man bestræbte sig på at vælge manuskripter, der ud fra de givne betingelser var velegnede som objekt for en digitalisering.

Hertil kommer, at det som nævnt jo ikke er masterbilledet, der transmitteres og i givet fald udprintes, men et afledt billede, der er forsøgt tilpasset de standarder for netværkskapacitet og skærmkvalitet, der gjorde sig gældende på produktionstidspunktet. Med de transmissionshastigheder, der også for private brugere er lige indenfor rækkevidde ${ }^{4}$, vil selv overførsel af meget store filer og altså billeder af bedre kvalitet ikke være noget problem. Til gengæld har teknologien indenfor skærmkvaliteten (endnu) ikke fulgt trop med denne udvikling. Som nævnt ovenfor kan produktet af digitaliseringskæden ikke blive bedre end de enkelte led tillader det. Med den skærmopløsning, der er standard i dag, er monitoren foreløbig digitaliseringskædens flaskehals. 


\section{Indeksering af digitaliserede manuskripter}

$\mathrm{T}$ ilgængelighedsproblemstillingen har et yderligere aspekt, der ikke vedrører den mere tekniske side af sagen mht. optagelseskvalitet og læselighed, men derimod det, man med et gængs begreb indenfor biblioteksverdenen kunne kalde for genfindingsproblematikken. Igen er det ikke en problemstilling, der er særegen for manuskripter, og igen er det en problemstilling, der i visse henseender er speciel og kan være særlig kompliceret ved visse manuskripter.

Det siger sig selv, at det skal være muligt at finde frem til, hvilke dokumenter, der er digitaliseret. De forskellige muligheder for at løse dette indlysende krav, skal jeg ikke komme nærmere ind på. Derimod er der i denne sammenhæng en afgørende forskel på analoge, fysiske og digitaliserede dokumenter. Når man søger i en traditionel kortkatalog (alfabetisk og/ell. systematisk) eller $i$ et online-søgesystem, henvises man til et fysisk dokument. Med dette i hånden bliver man 'foræret' andre strukturelle typer af indekseringer på et lavere niveau end de overordnede, der vedrører forfatter, titel og evt. emne. Det kan være en indholdsfortegnelse, indeks i snævrere forstand, bilag m.v. Hertil kommer, at det fysiske dokument er en sammenhængende enhed, der gør det let at "browse", skrålæse, vende tilbage til tidligere læste afsnit osv.

De enkelte billeder i en digitaliseret samling af dokumenter udgør.ikke i sig selv en sammenhæng. Bitsene er nytteløse med mindre disse digi- tale billeder forsynes med metadata, der kan lænkes til det elektroniske søgesystem. Når man søger $\mathrm{i}$ en dokumentdatabase, søger man ikke i billedfilerne, men $i$ en referencedatabase, der refererer til de enkelte billedfiler. Det er derfor afgørende, at de enkelte filer kan refereres til med en entydig henvisning, og at systemet er i stand til at holde rede på referencerne på en entydig måde. Eller med andre ord: man må anvende de nødvendige resurser på at tilføje de strukturelle metadata, der kan beskrive den interne struktur, som det fysiske dokument uden videre 'forærer' én.

Dette kan generelt set forekomme temmelig simpelt, men vil dog i forbindelse med digitalisering af visse manuskripter og samlinger af manuskripter kunne frembyde en del problemer. I de tilfælde, hvor det drejer sig om et enkelt manuskript med en relativ simpel struktur, der på forhånd er velregistreret, f.eks. et middelaldermanuskript, vil man kunne genbruge de eksisterende data, så der kan søges på eksempelvis hovedafsnit, sidetal og bestemte illustrationer. Problemerne opstår på grund af mange manuskriptsamlingers og i disse mange dokumenters heterogene karakter. Den fysiske enhed, der består i kraft af en såkaldt "bindekapsel”, består gerne af flere læg, og i hvert læg kan der være indtil flere selvstændige dokumenter, der består af en eller flere sider. De enkelte dokumentsider og dokumenter er knyttet til hinanden ved fysisk nærhed, på samme måde som de enkelte kapsler i mange tilfælde er knyttet sammen i kraft af deres fysiske opstilling. Den meget væ- 
sentlige information, der ligger $\mathrm{i}$, at 2 dokumentsider er 2 sider af samme ark, at 2 ark hænger sammen, eller at 2 dokumenter befinder sig i samme kapsel eller på samme magasinhylde forsvinder, når dokumenterne digitaliseres og lagres elektronisk. Et andet problem kan bestå $\mathrm{i}$, at adskillelsen mellem dokumentsider ikke altid er velegnet som udgangspunkt for en representation af informationsindholdet. F.eks. kan en tilskrift i margenen strække sig over indtil flere sider.

Pointen er ikke, at sådanne problemer ikke kan løses. Pointen er, at skal de løses på en måde, der på én gang udnytter den tilgængelighed, som de elektroniske medier muliggør, og som et mindstekrav reproducerer de fysiske dokumenters eksterne og interne strukturelle sammenhænge, at det da vil kræve et betz'deligt registreringsarbejde og altså indførsler af metadata, der ikke blot og bart kan bygge på eksisterende data.

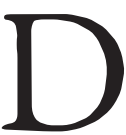
e metadata, der er omtalt ovenfor, er beregnet på at kunne finde et bestemt digitaliseret dokument og gøre det lettere at finde rundt i det. Jo færre resurser, der anvendes til dette formål, jo mere risikerer man at lade brugeren i stikken. Imidlertid findes der en anden type af data, der kan knyttes eller lænkes - til dokumentet, nemlig intellektuelle data, der ikke på samme måde er nødvendige, men som i høj grad kan lette tilegnelsen af dokumentet. For denne type af data er det alene de $ø$ øonomiske og intellektuelle resurser, der sætter begrænsningerne for deres anvendelse. Det drejer sig typisk om den form for data man ser i forbindelse med (videnskabelige) udgivelser af et værk: indledning, placering $i$ tid og sted, kommentarer, noter, fortolkning, bibliografi osv. Det er muligt - og oplagt - også på Internettet elektronisk at publicere den type af udgivelser, der tidligere var forbeholdt bogmarkedet og som man i øvrigt før Nettet for alvor slog igennem tog op elektronisk på cdrom $^{5}$. Cd-rom-mediet har hidtil haft 2 klare fordele. For det første at det var muligt at levere en bedre billedkvalitet hurtigere end det var tilfældet på Nettet. For det andet at det som et kommercielt produkt kunne dække (nogle af) udgifterne ved et projekt. Jeg skal ikke komme nærmere ind på det økonomiske aspekt i denne sammenhæng, men blot nævne, at der naturligvis også er udtænkt tanker om - og strategier for - , hvordan man forhindrer uformidlede brugeres adgang til udvalgte data på Nettet. Og hvad angår billedkvalitet og hastighed vil cd-rom'en miste sin enestående betydning i takt med den netværkshastighed, der som nævnt er lige indenfor rækkevidde.

\section{Digitalisering af hvad og for hvem}

T lyset af ovenstående er svaret ikke umiddelbart indlysende. Man skal naturligvis på den ene side (bevaringsaspektet) digitalisere de manuskripter, der ikke på længere sigt tåler daglig benyttelse, på den anden side (kommunikationsaspektet) de eftertragtede manuskripter, som kræver en flybillet fra San Francisco til København, og på den tredje side (offentligheds- 


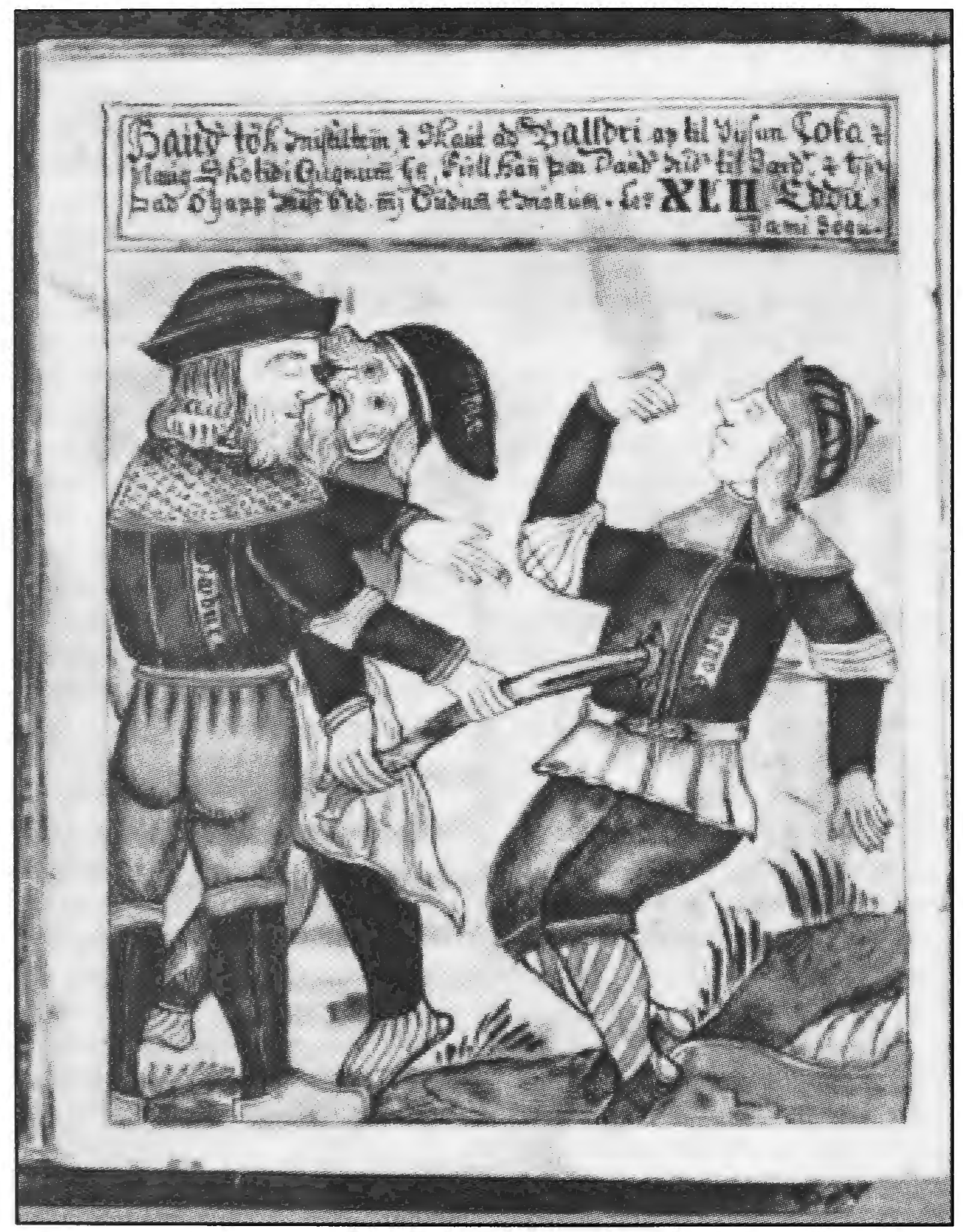

Et andet af de manuskripter, der vil blive digitaliseret af Håndskriftafdelingen, er Samunds Edda, et islandsk gudebaindskrift.

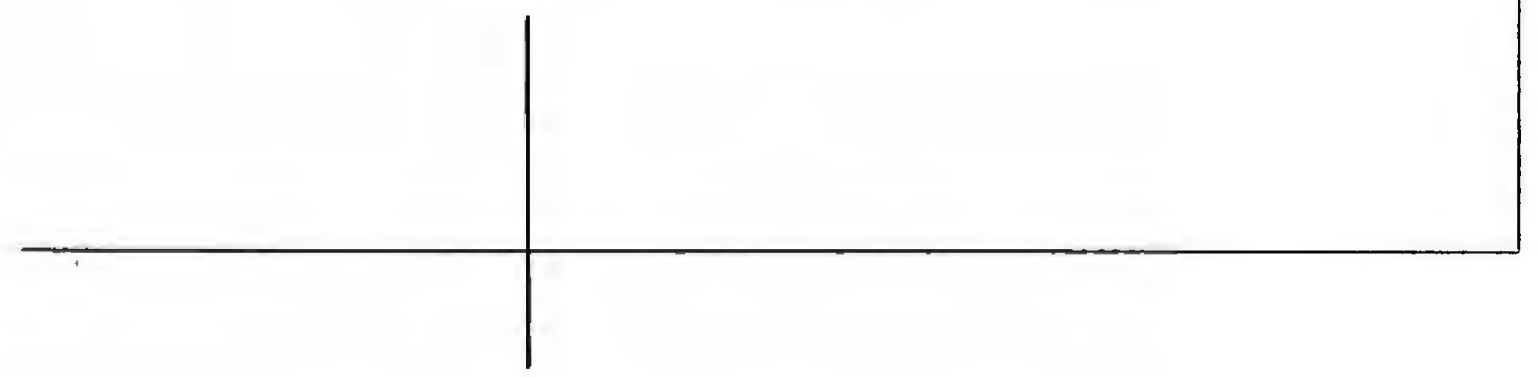


aspektet) manuskripter, som er oppe i tiden eller som kan indgå i en udstillingsvirksomhed.

Selv om disse hensyn ikke naturnødvendigt på forhånd udelukker hinanden, kræver de et valg, hvor planlægningen på én gang må tage ideelle og praktiske hensyn. Alt hverken kan eller skal gøres tilgængelig over Nettet. Og det tilgængeliggjorte materiale vil normalt $i$ en lang årrække være en forsvindende lille del af det materiale, det indgår som kontekst i. Eller med andre ord: det middelaldermanuskript eller det manuskript af H. C. Andersen, eller den dagbog eller de breve, der digitaliseres, har deres egen sammenhæng, hvor den umiddelbare tilgængelighed automatisk kræver mere. "Less is more" $\mathrm{i}$ en lidt anden betydning end den gængse.

På lidt længere sigt er der alligevel ikke udelukkende grund til at betragte digitalisering af manuskripter som 'udstillinger'. Selv om der - formentlig - altid vil være $10 \%$, der vil hævde, at de nødvendigvis skal se originalmanuskriptet, så vil opbygningen af digitale samlinger være en klar fordel for biblioteket og brugerne.

En afgørende gevinst, men også den egentlige hensigt med digitalisering af manuskripter, er at overflødiggøre bibliotekets læsesal. I stedet for at skulle opsøge biblioteket, rådføre sig med dets personale, bestille de ønskede manuskripter, afvente deres levering til læsesalen, foretages dokumentleveringen af brugeren selv via dennes Personal Computer. Det er klart, at studiet af et dokument altid i sidste ende vil være en individuel affære. Men det er lige så klart, at det fysiske, analoge dokument automatisk implicerer en social og kulturel kontekst, som forsvinder med det elektroniske. Eksisterende begreber som 'studie-' og 'forskermiljøer' vil ikke nødvendigvis blive ukurante i fremtiden, men det kan meget vel blive nødvendigt at give dem et nyt indhold. Man behøver ikke være spåmand for at se, at miljøerne i endnu højere grad end i dag vil blive elektroniske, hvor man med det samme dokument eller forskellige typer af dokumenter foran sig fra hvert sit hjørne af verden kan udveksle erfaringer og dokumenter, stille spørgsmål, komme med idéer osv. Spørgsmålet er så, hvorvidt og i hvilket omfang denne elektroniske kommunikation kvalitativt kan og vil erstatte den personlige kontakt - på biblioteket, på instituttet, i studerekammeret.

Hvis hensigten med digitaliseringen - ganske vist hårdt trukket op - er at overflødiggøre bibliotekets læsesal, så ligger heri eo ipso at hensigten med det digitale dokument er at overflødiggøre brugen af det originale manuskript. Manuskripterne destrueres ganske vist ikke, men bliver til 'arkivalier'.

Hvis denne hensigt skal opnås, vil der blive stillet nogle naturlige krav til kvaliteten af den fremviste digitale reproduktion, der i mange tilfælde kun vanskeligt - om overhovedet - kan indfries $\mathrm{i}$ dag. Og for visse typer af manuskripter og for studiet af dem er det et spørgsmål, om det nogensinde vil kunne lade sig gøre. F.eks kan studiet i papirkvalitet og vandmærker, der kan være afgørende for bestemmelsen af et manuskripts proveniens og tidsmæssige place- 
ring, jo ikke foretages i den elektroniske reproduktion. Noget andet er, at resultaterne, én gang fundet, uden videre kan lænkes til denne reproduktion. Et andet eksempel på den kvalitet, som forskere med rimelighed vil kunne forvente, er, at den informationsværdi, der kan ligge i pennens tryk mod papiret som udtryk for affekt, skal 'digitaliseres'.

Man kan mene, at man med det sidste eksempel er kommet for langt ud. Men som det er blevet fremhævet ovenfor, så er manuskripter $\mathrm{i}$ informationsmæssig henseende multidimensionale. Hertil kommer endelig det aspekt, som jeg med ét ord vil kalde for det astetiske, og som udover det informative vedrører noget så uhåndterligt som følelser, stemninger, associationer m.v. Enhver, der har siddet med originalmanuskriptet til et af $\mathrm{H}$. C. Andersens eventyr i hånden - det er ganske vist relativt fa - vil vide, at det er en oplevelse, som selv digitale billeder af højst opnåelige kvalitet ikke kan viderebringe.

Dette være ikke sagt for at plædere for "a conservative approach". Morten Hein citerer i sin artikel "Aesthetics and Quality in Format Conversion" følgende bon mot. "The future comes by itself - to achieve progress you have to make an effort." ${ }^{6}$ Han stiller kritiske spørgsmål til den imponerthed, man let gribes af, når fremtiden åbenbarer sig i nutiden: "Everyone among the Internet freaks was amazed by the fact that a Rolling Stones concert was "televised" in Internet early in 1995 in a small window in a screen at a rate of frames per second at one third the normal - if the bandwidth allowed so. This was named an achievement but can scarcely be one hundred years after the Lumière brothers and their first moving images."

Og han kommer med mange eksempler på, hvordan elektroniske dokumenter gennem fire årtier har ødelagt vores krav til kvalitet. Først var det fotokopien og kopier af kopien, og nu hvor fotokopierne er blevet af langt bedre kvalitet, er det faxmaskinen, der har bragt ".. a new dimension to the deterioration of documents." Det er i lyset af disse erfaringer, han udtrykker en vis skepsis overfor de mange bestræbelser på at opbygge det virtuelle bibliotek. $\mathrm{Og}$ det er på denne baggrund, at virkelig "fremskridt" forudsætter, at imponertheden holdes i ave, sà "indsatsen" kan bygges på et uhildet krav om kvalitet. Hans "Lack of Conclusion" passer fint med de erfaringer og problemstillinger, der møder én - også når man beskæftiger sig med digitalisering af manuskripter!:

"I have no conclusion except the wish to convey my desire to encourage the libraries to take aesthetics and quality assurance into consideration in the coming process of creating electronic documents." 8 
Noter

1 Hele historien og samtlige notesbøger er tilgængelige på adressen: http://lcweb2. loc.gov/wwhome.html

2 Efter afslutningen af det igangværende digitaliseringsprojekt på Island, SagaNet, kalkulerer man med at reducere anvendelsen af originalmanuskripterne til de islandske sagaer med $90 \%$.

3 Jvf. f.eks. Peter Robinson: The Digitization of Primary Textual Sources, Oxford 1993, s. 12.

- Efter indflytningen i 'Diamanten' vil nethastigheden for Det Kongelige Biblioteks ansatte og brugere i teorien blive på 34 megabits pr. sekund. Privat vil man med ADSL, som Tele Danmark har planer om at indføre, kunne nå op på langt højere hastighed end den, der nås i dag ved anvendelsen af de gængse modems.

5 Et af de bedste - og meget resursekrævende - projekter er Aberdeen University Library's Bestiary Project, der findes på adressen: http:I/www.clues.abdn.ac.uk:8080/ besttest/firstpag. html

* Morten Hein: "Aesthetics and Quality in Format Conversion", i: Helal, Ahmed H. \& Weiss, Joachim W. (ed.s): Electronic Documents and Information: From Preservation to Access, Publications of Essen University Library 20, Essen 1996. Side 199.

7 Id, s. 201.

Id, s. 207 